\title{
RODENT SPECIES \\ IN URBAN CEMETERIES OF CHISINAU CITY, REPUBLIC OF MOLDOVA
}

\section{Natalia Caraman¹, Galina Tikhonova², Igori Tikhonov², Elena Kotenkova ${ }^{2}$}

\author{
${ }^{1}$ Institute of Zoology, Chisinau, Republic of Moldova, CNatusea@yahoo.com \\ ${ }^{2}$ Institute of Ecology and Evolution RAS, Moscow, Russia, evkotenkova@yandex.ru
}

Abstract. The research has been conducted in 3 biggest cemeteries of Chisinau city: Central ("Armenian"), "Saint Lazarus" ("Doina") and Jewish. We found 9 species of small mammals (7 species of rodents and 2 shrews). Species of rodents were Clethrionomys glareolus, Microtus rossiaemeridionalis, Apodemus flavicollis, A. sylvaticus, A. uralensis, Rattus norvegicus and Mus musculus and 2 shrew species - Sorex araneus and Crocidura suaveolens. A.sylvaticus was dominant species, followed by $M$. rossiaemeridionalis and A. flavicollis.

\section{Introduction}

In recent decades the world has undergone rapid change, including population explosions and massive urbanization [4] as a result of human activities has affected natural ecosystems $[5,7]$. That is why there are more and more that refer to the ecological divergence in animal species. Small mammals are an important object of study in the sense of synanthropy, because they quickly adapt to the anthropogenic disturbances and to human presence. The importance of studying the synanthropy of small mammals in the urban environment explains, first of all, the conditions for their coexistence with humans.

Urban regions may be cities or towns and are characterized by closely located buildings and by higher human population density compared to areas surrounding it. Among rodents occupying urbanized territories, it is easy to distinguish two major groups. One group represented by two synanthropic species of rodents: rat (Rattus norvegicus) and house mouse (Mus musculus), which are highly adapted to survive within urban landscapes and can be found throughout the world. The other group is represented by rodent species that may be found within city limits most of them are more common outside of human dwelling and are adapted to a natural environment [6].

In the Republic of Moldova, more intense researches of urban fauna were performed after $2000[1,8,12]$. Thus, researches were carried out in the forests of the municipality and its surroundings [11], as well as in various types of more or less anthropized biotopes of Chisinau city. Cemeteries are exceptional places in the cities. These areas are cut off from the noise of the city and the night lights are not as bright. The old trees and even the graves constitute good shelters for the small mammals [2]. City cemeteries are often bordered by parks or green areas, creating more favorable shelters for small mammals. This part of the biota of Chisinau city remains poorly studied [8]. The aim of the study was to reveal the diversity and abundance of small mammal species in several cemeteries of Chisinau city. 


\section{Materials and methods}

The research has been conducted in 3 biggest cemeteries: Central ("Armenian"), "Saint Lazarus" ("Doina") and Jewish in October-November 2008.

The Jewish Cemetery is one of the oldest cemeteries in Chisinau city, Republic of Moldova. It is a historical monument and art of national category, which has been operating since 1887, although the first tombs are attested from the beginning of the century XIX, and other sources attribute an age from 200 to almost 300 years (fig. 1). Different sources expose the dimensions of the preserved part of the cemetery. It would cover an area of 11, 12 or 15 hectares and would have about 24 thousand or over 40 thousand graves. Also here is a funeral synagogue, unique in Moldova, now ruined. In the cemetery there are a lot of tombs and monuments over a century old. A monument with a propeller is installed at the tomb of an aviator, which is still rotating today.

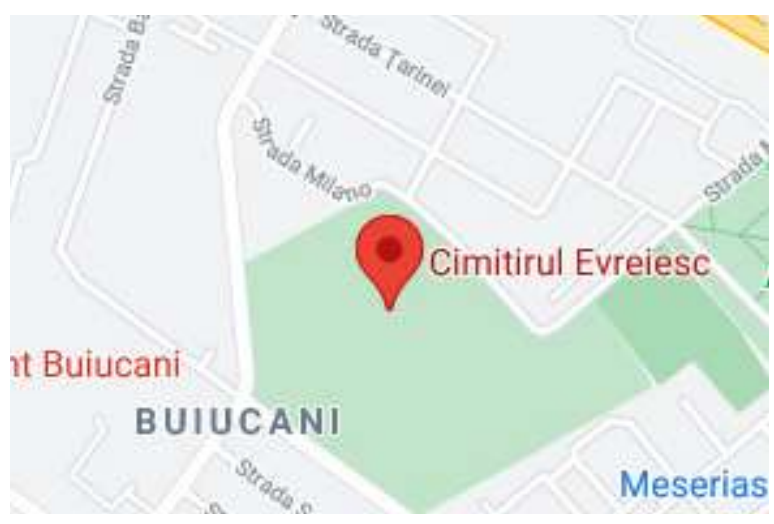

Figure 1. Location map of the Jewish cemetery

The central cemetery in Chisinau city, improperly called the Armenian cemetery, is one of the most famous cemeteries in the Republic of Moldova. Founded in 1811, it is the resting place of many prominent personalities in the history and culture of Moldova. The cemetery is located in the Center sector of Chisinau city (fig. 2). Although it is the oldest cemetery in Chisinau city, it is not found among other cemeteries with protected status, included in the "Register of Monuments of the Republic of Moldova". 


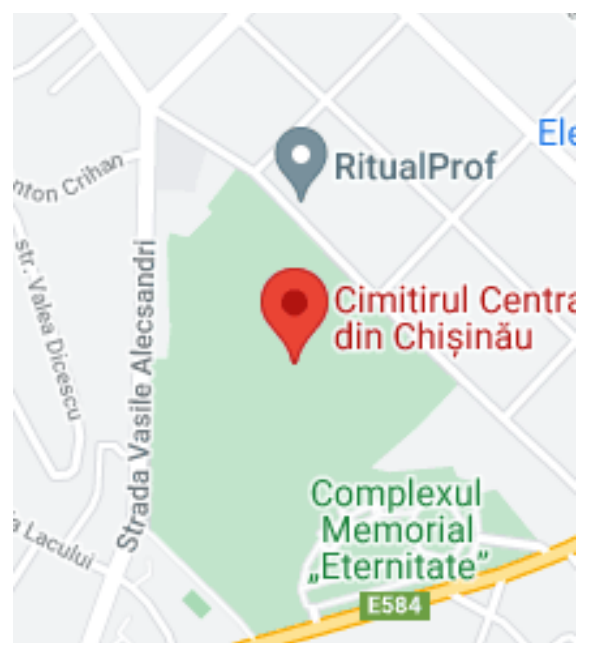

Figure 2. Map of the location of the Armenian cemetery

St. Lazarus Cemetery, called colloquial Doina Cemetery, is a cemetery located in the Old Post sector in Chisinau city. It is one of the largest cemeteries in Europe, the area is about 2,000,000 m2 (fig. 3). It was opened in 1966 and currently has over 300.000 graves, including 600 graves, being divided into 266 sectors.

The material was collected with snap traps, the total effort was 390 trap-nights. The traps we placed in lines at the distance of $5 \mathrm{~m}$ between the traps and 25 to $50 \mathrm{~m}$ distance between the rows. As bait small pieces of bread imbued with sun-flower oil were used.

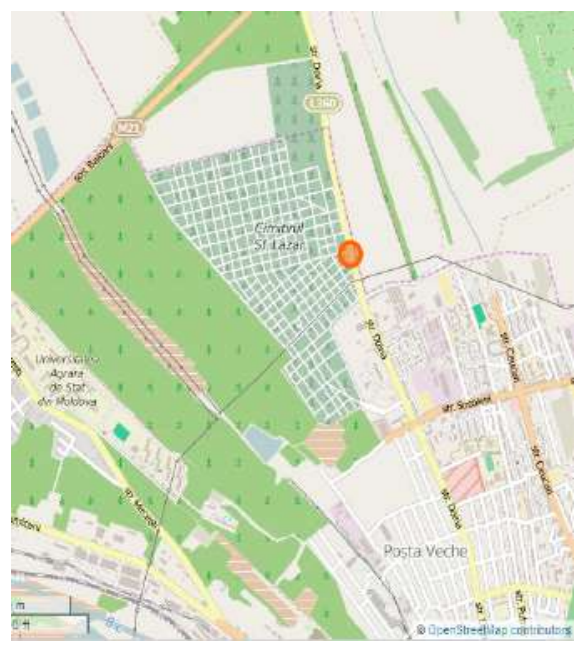

Figure 3. Location map of the "Doina" cemetery

The statistical analysis was performed using the programs Microsoft Excel and BiodiversityPro. 


\section{Results and discussions}

During the study there were collected 78 individuals from 7 species of rodents (Clethrionomys glareolus, Microtus rossiaemeridionalis, Apodemus flavicollis, A. sylvaticus, A. uralensis, Rattus norvegicus and Mus musculus) and 2 shrew species (Sorex araneus and Crocidura suaveolens).

As result of the analysis of the total abundance and capture coefficient on the cemeteries, it was found that the cemetery with the richest fauna of small mammals was "Doina" cemetery with an abundance of $82.1 \%$ with total capture coefficient was $8.7 \%$, followed by Jewish cemetery with abundance of $15.4 \%$ and the capture coefficient was of $3.1 \%$. Due to the location of the Armenian cemetery in the center city and largely surrounded only by buildings, only one species was captured, Rattus norvegicus - typically synanthropic with $2.6 \%$ abundance and capture coefficient of $0.5 \%$.

The dominant species was $A$. sylvaticus, a capture coefficient of $7.2 \%$ and an abundance of $35.9 \%$, followed by species $M$. rossiaemeridionalis and $A$. flavicollis which had a capture coefficient of $3.8 \%$ and an abundance of $19.2 \%$ each, and $A$. uralensis with c.c. $2.1 \%$ and an abundance of $10.3 \%$. The least abundant rodent species was C. glareolus and R. norvegicus which had abundence $3.8 \%$ and capture coefficient of $0.8 \%$ each. The typical synanthropic species $\mathrm{M}$. musculus had an abundance of $1.3 \%$ and capture coefficient of $0.3 \%$. In several European cities the species A. sylvaticus also dominates in similar cenoses $(3,9,10)$.

Among the shrews, two species were identified: $C$. suaveolens with a total abundance of 3.8 and c.c. $0.8 \%$ and $S$. araneus had abundance $-2.6 \%$ and c.c. $0.5 \%$.

In the Jewish cemetery, which is an old cemetery, 4 species of rodent and 1 shrew species were observed. The dominant species was A. sylvaticus with $41.7 \%$, followed by A. uralensis $33.3 \%, C$. glareolus and $R$. norvegicus had the abundance of $8.3 \%$ each. The shrew species $C$. suaveolens had an abundance of $8.3 \%$ (fig. 4).

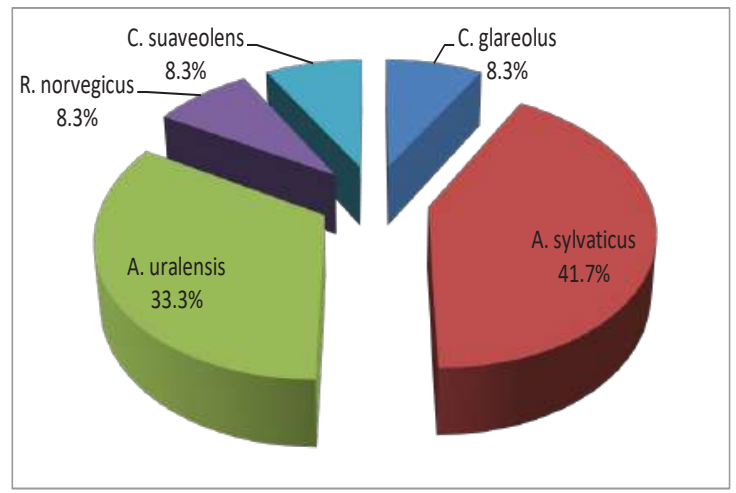

Figure 4. Abundance of small mammal species in the Jewish cemetery

Location of the "Doina" cemetery outside the city surrounded by different types of biotopes allows to support a richer fauna than the other studied cemeteries. In "Doina" cemetery A. sylvaticus was the most abundant species with $35.9 \%$ and catch coefficient of $10.9 \%$, followed 
by $A$. flavicollis and M. rossiaemeridionalis with $23.4 \%$ and $7.1 \%$ catch coefficient for each species. The rodent species with a lower abundance were A. uralensis with $6.3 \%$ and catch coefficient $-1.9 \%$, followed by Clethrionomys glareolus, which is a silvicolous species and had an abundance of $3.1 \%$, a capture coefficient of $0.9 \%$, due to the fact that the cemetery is surrounded by a recreational forest. The synanthropic species $M$. musculus had an abundance of only $1.6 \%$ and a capture coefficient of $0.5 \%$.

The shrew's species $C$. suaveolens and $S$. araneus had abundance of $3.1 \%$ and capture coefficient of $0.9 \%$ for each species (fig.5).

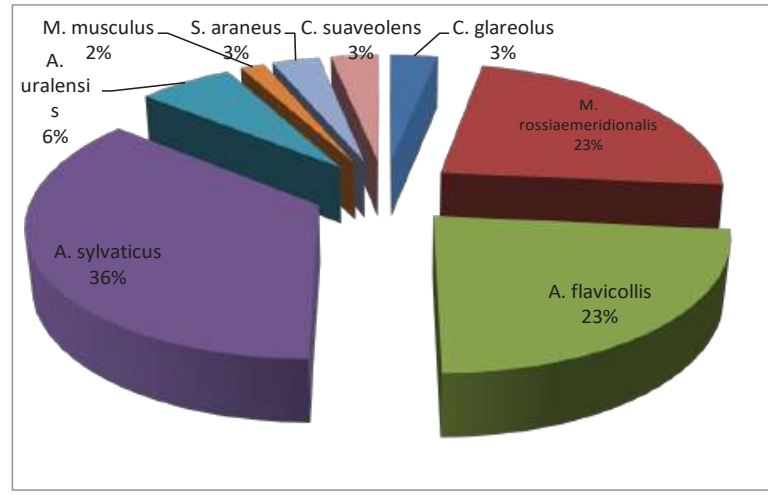

Figure 5. Abundance of small mammals in the "Doina" cemetery

In present conditions many small mammal species manifest remarkable adaptive capacities. Therefore, in the last years, in spite of the anthropic pressure, small mammals, especially common rodent species are constant in various types of anthropized ecosystems, even in cemeteries. The adaptive potential of small mammals consists of the use of a large trophic spectrum of resources, the high reproductive potential, as well as the extensive period of reproduction activity.

\section{Conclusion}

Nine species inhabit in the cemeteries of Chisinau city, of which A.sylvaticus dominated. The second most abundant species of rodents were $M$. rossiaemeridionalis and A. flavicollis.

In the cemeteries of Chisinau there was a fairly rich and variable fauna of small mammals due to the existence of various types of biotopes in "Doina" cemetery, including semi-natural ones, which favor the presence of stable rodent and shrew community, which in turn favors the existence of a series of vertebrates that consume them.

The study was carried out within the bilateral project between Russia and Moldova 08.82008.14R and State Program project 20.80009.7007.02. 


\section{Bibliography}

1. Chicu V., Uspenschii I., Melnic V., Culibacinâi E., Guţu A., Gheorghiţa S., Conovalov Iu., Movilă A. Unele particularităţi ecologice şi epidemiologice ale focarelor urbane de zooantroponoze.Materialele conferinţei ştiinţifice internaţionale, Chişinău, 2002, p. 262-265.

2. Csanády A., Moshansky L. Public Cemetery as a biodiversity hotspot for birds and mammals in the urban environment of Kosice city (Slovakia). Zoology and Ecology, Volume 27, 2017 Issue 3-4, 2017. Pp 185-195.

3. Elvers H., Elvers K.L. Verbreitung und Okologie der Waldmaus (Apodemus sylvaticus L.) in Berlin (West). Zool. Beitr. N. F. 1984. Bd. 28. S. $403-415$.

4. http://apps.who.int/iris/bitstream/10665/112667/1/WHO_HSE_GCR_LYO_2014.4_eng.pdf

5. http://bibliofond.ru/view.aspx?id=520316,

6. Khlyap L., Glass G., Kosoy M. Rodents in urban ecosystems of Russia and the USA. In Rodents: Habitat, Pathology and Environmental Impact. Ed. Triunveri A., Scalise D. 2012. Nova Science Pub Inc. pp. 1-22.

7. Steidl Robert J. and Powell Brian F.. Assessing the Effects of Human Activities on Wildlife. The George Wright Forum. Visitor Impact Monitoring. Vol. 23, No 2 (2006), p. 50-58.

8. Tikhonov I., Muntyanu A., Uspenskaya I., Konovalov Yu, Burlaku V., Karaman N., Nistreanu V., Tikhonova G., Kotenkova E. Biotopic Distribution, Population Structure, and Some Features of Small Mammal Reproduction in Chisinau city. Biology Bulletin, 2012, Vol. 39, No. 10, pp. 839-845.

9. Клауснитцер Б. Экология городской среды. М.: Мир, 1990. 248 с.

10. Пеликан Я., Гомолка М., Зейда Я., Голишова В. Мелкие млекопитающие агломерации на примере г. Брно. Studia Geographica (Brno). 1980. Т. 71, № 1. С. 95 - 104

11. Тихонов И.А., Котенкова Е.В., Успенская И.Г., Коновалов Ю.Н., Бурлаку В.И., Бенеш О.А., Георгица С.Д., Караман Н.К., Тихонова Г.Н., Хрыстин В.А., Нистреану В., Мунтяну А.И. Грызуны и насекомоядные незастроенных территорий г. Кишинева (Rodents and Insectivora of unbuilding territories of city Kishinev). Proceedings of 4th International Scientifical-Practical Conference "Urboecosystems: problems and Prospects of Development", Ishim, 19-20 March, 2009, p. 310-315.

12. Успенская И. Г., С.Д. Георгица, В.Ф. Кику и др. Структурно - функциональная организация очагов зооантропонозов в условиях урбаценоза г. Кишинева. Москва, РЭТ инфо, Nr.2 (50) июнь, 2004, стр. 21-23. 